\title{
City-To-City Learning for Urban Resilience: The Case of Water Squares in Rotterdam and Mexico City
}

\author{
Silvana Ilgen ${ }^{1}$, Frans Sengers ${ }^{1,2}$ and Arjan Wardekker $1,3, * \mathbb{D}$ \\ 1 Copernicus Institute of Sustainable Development, Utrecht University, P.O. Box 80115, 3508TC Utrecht, \\ The Netherlands; silvana.ilgen@gmail.com (S.I.); F.Sengers@uu.nl (F.S.) \\ 2 Department of Geography, King's College London, 40 Aldwych, London WC2B 4BG, UK \\ 3 Centre for the Study of the Sciences and the Humanities, University of Bergen, P.O. Box 7805, \\ 5020 Bergen, Norway \\ * Correspondence: J.A.Wardekker@uu.nl; Tel.: +31-30-253-4407
}

Received: 11 April 2019; Accepted: 7 May 2019; Published: 10 May 2019

\begin{abstract}
Cities worldwide are building 'resilience' in the face of water-related challenges. International networks have emerged through which urban communities draw on each other's experiences and expertise in order to become resilient cities. Learning is a key principle in resilience-building, but thus far little empirical research is available on city-to-city learning and learning for urban resilience. This paper presents an analysis of how policy relevant knowledge on the notion of 'Water Squares' is exchanged between Rotterdam and Mexico City. We mobilize a framework composed of four distinct phases: exploration and marketing (phase 1), building pipelines (phase 2), translation and adoption (phase 3), and internalization and reflection (phase 4). Critical in first phase was introspective analysis of one's own systems, strengths and weaknesses, rather than an outward-looking search for knowledge or mentees. During the second phase, the cities reframed their own narratives to match those of their counterparts as a way to create a mutual understanding of each other's struggles and histories. This facilitated policy and knowledge exchange as equal partners on a basis of trust. In the third phase, strong local leaders were recruited into the process, which was key to anchor knowledge in the community and to reduce the risks of losing institutional memory in centralized, hierarchical institutions. For the fourth phase it should be stressed that by internalizing such lessons, cities might strengthen not only their own resilience, but also enhance future exchanges with other cities.
\end{abstract}

Keywords: city-to-city learning; policy transfer; resilient cities; water squares

\section{Introduction}

More than half of the world's population lives in cities and these numbers are still rising [1]. Cities are under intensive pressure to accommodate the needs of these rapidly growing populations, including providing adequate and safe housing, production activities and work, and resources such as energy, food, and water. The expansions of cities and the urban adaptations that were made have given rise to sprawling metropolises beset by a range of social and environmental problems [2]. Many current and future global challenges relate to the interaction of urbanization and its social and environmental impacts, and cities may therefore host both the problems but also the potential solutions to these challenges [3].

Climate change is a key sustainability challenge to the future development of cities. Potential effects of climate change range from flooding to drought, impacts on water quality and availability, and impacts on critical infrastructures, health, food supply, tourism, biodiversity, housing, and communities [1]. These can result in short-term disruptions and disasters in cities, as well as have a 
broader and long-term influence on urban resource and population dynamics and environmental and social equity. In cities worldwide, and in developing countries in particular, these impacts are expected to also exacerbate numerous existing problems $[1,4,5]$. The impacts and their interactions with other societal challenges are, however, complex and uncertain [6]. The need is widely recognized for societies at large, and cities in particular, to better promote and govern a transition towards sustainability [7-9]. This includes mitigation, reducing greenhouse gas emissions, but also making cities more resilient to climate change and other social, economic, and environmental challenges [8-10].

The notion of 'urban resilience' has become prevalent in urban thinking. The Habitat III New Urban Agenda [9], for instance, focuses considerable attention on the need to improve urban resilience, including to climate change. Resilience is one among a number of urban sustainability concepts, such as 'smart', 'low carbon', and 'eco cities' [11]. The term 'resilient city' refers an urban area that has the ability to withstand and cope with a wide range of shocks and stresses, including the ability to plan/prepare, absorb, recover, and adapt to such disturbances $[12,13]$. The literature on urban resilience encompasses a wide range of scientific fields, including urban ecology [14,15], urban hazards and disaster studies [16,17], urban and regional economics [18], governance and institutions [19], spatial planning [20-22], and climate change adaptation [12,23]. Resilience is particularly focused on living with change and coping with disturbances in complex adaptive systems, with multiple pressures, economic sectors, policy fields, and scientific disciplines involved, and high levels of uncertainty [22-27]. Urban water systems are a prime example of such a situation, combining highly interwoven social, ecological, and technical systems with changing and highly uncertain pressures and requirements due to climate change and a multitude of other urban trends [28,29]. In many places, water scarcity and uncertainty are already forcing a re-think about the way governments manage their water resource systems [19]. Urban water reforms and adaptations should result in resilient water systems that explicitly take into account complexity, uncertainty, and immediate and long-term change [30].

Many cities are now incorporating resilience thinking into urban planning at large, and specifically with regard to climate change adaptation. Different cities will (or may want to) opt for different strategies to improve resilience, and toolkits have been developed to design resilience strategies and policy options appropriate for a city (e.g., [31-35]), and to scrutinize choices and trade-offs made in that process (e.g., [36-39]). Several international organizations and networks have been established to stimulate resilience-building, as well as actively exchange policies and knowledge as a way to facilitate mutual learning. Examples include Local Governments for Sustainability (ICLEI), the Asian Cities Climate Change Resilience Network (ACCCRN), and 100 Resilient Cities. On the broader topic of sustainability, a wide range of such networks has emerged, often with a similar organization, large role for regionally-oriented cities, but irregular representation of developing regions [40]. The importance and potential of such networks for improving systems and building sustainability and resilience is widely recognized [40-44]. Policy exchange, knowledge transfer, and learning in these networks can help cities enhance policy innovation [44-46]. For urban policymakers, their peer network in other cities, and exchanges through conferences and city networks, are key sources of information and new ideas [47]. According to an UNESCO-IHE flyer [48], advantages of city-to-city learning include: accelerated transfer of knowledge and experience, joint knowledge creation, empowerment of local governments, reinforcing local networks, enhancing collective memory of participating cities, and increasing learning capacity. Learning is also described as a key characteristic of resilient socio-ecological systems, including cities [5,49]. However, individual cities learn in different ways [50], and full social learning can be hampered in situations of diverging perceptions, framing, values, interests, and levels of power [5]. Between cities, further difficulties may emerge due to differences in the culture and language, specifics of the local situation, institutions and regulations, and even the specific ways in which agents and persons involved in the knowledge and policy transfer act or handle the situation $[40,46]$. Consequently, while cities can learn much from each other, stimulated by the resources and reach of transnational city networks, such knowledge and policy transfer may not always run smoothly and requires constant dedicated work [51]. 
At the moment little is known about the mechanisms that underpin knowledge and policy transfer on urban resilience among cities, and about what barriers and stimuli that influence this process. The literature available on the topic is often prescriptive rather than descriptive [52]. Clearly, it is not simply a matter of cutting and pasting from one location to another. Cities are already actively trying to exchange ideas and best practices, and there is a need for more systematic knowledge on how this can be facilitated. This paper examines a case where such policy transfer is actively and intentionally pursued, using a preliminary analytical framework. Particular attention will be paid to the actors, processes, practices, and structures involved in the transfer. This study will focus on the transfer of resilience thinking and practices between Rotterdam and Mexico City, and will draw lessons from the observations made in this process. More specifically, we will investigate city-to-city learning around the notion of the Water Square-a best practice project already implemented Rotterdam and yet to be implemented in Mexico City.

\section{Materials and Methods}

To investigate city-to-city learning for the transfer of policy and adaptation measures to build urban resilience in the context of climate change, we conduct an empirical, in-situ analysis. Our approach can be described as an 'explanatory case study' because we do not only explore or describe in-situ learning but also develop theory to deepen our understanding of key processes or mechanisms and [53,54]. We examine the case of Mexico City and Rotterdam, two cities currently actively engaged in a process of policy and knowledge exchange, particularly on Rotterdam's concept of Water Squares (Section 2.1). Tangible best practices projects like water squares are of special interest here because they became focal points in collaboration efforts and a vessel that facilitated much wider transnational knowledge flows and broader lessons about urban resilience in general. We examine this process of city-to-city learning sparked by these water squares in action through semi-structured interviews, site visits, and participant observation (Section 2.2). This process is assessed using a preliminary analytical framework (Section 2.3).

\subsection{Case Study}

The resilience literature widely acknowledges learning as a key aspect in the resilience of complex adaptive systems, including cities, and crucial for policymaking under uncertainty and complexity $[5,12,52,55-58]$. In such cases knowledge is always incomplete and change and surprise are inevitable [48] Learning is related to capacities, such as innovativeness and resourcefulness, as well as to practices and relations, such as experimentation, knowledge sharing, and collaboration. Learning has been used loosely in the resilience literature, combining notions of individual, organizational, and social learning [57]. Bahadur and Thornton [52] observe that much of the resilience literature is prescriptive on learning-describing practices that cities employ to stimulate learning. They argue that a closer, more practical look at learning in empirical context is needed, exploring the situational aspects that determine whether learning occurs or faces barriers, in order to overcome the current idealized and prescriptive notions of knowledge and learning for urban resilience. In line with this reasoning, this paper will explore a case of learning for resilience from an empirical in-situ standpoint: as the process of learning unfolds.

To develop such an in-situ understanding, we investigate the case of policy and knowledge transfer between Rotterdam and Mexico City. This entails an effort to 'mobilize' knowledge from Rotterdam to enhance water resilience in Mexico City. Both cities have flooding-related vulnerabilities, and Rotterdam has been very active (and successful) in flood risk management. Both cities are still searching for options that will enhance their water resilience. Both have appointed 'Chief Resilience Officers' and recently published a 'Resilience Strategy' [59,60]. There are also notable differences, including geographic, cultural, political, and institutional, that could influence the successfulness and ease of policy and knowledge transfer. A coordinated effort has recently been started to exchange 
experiences and knowledge, providing a valuable opportunity to study this process in action. We will briefly discuss the background of both cities and the water squares case.

Mexico City (Mexico) is a city of 8.9 million residents (city proper), with a subtropical highland climate. The city is located in the lower part of the Mexico Valley Basin around $2200 \mathrm{~m}$ above sea level, in a former lakebed surrounded by mountains. The lake system used to act as natural drainage for precipitation run-off, which was carried down by rivers and streams from the higher elevations that surround the basin. The hydraulic cycle of the lake system has been extremely and irreversibly transformed. Mexico City has made some achievements in water management, but continues to face challenges and vulnerabilities to flooding and water availability due to the structural features of the water system, changed hydrological cycle in the basin, and unequal access to supply and to drainage services [61]. Mexico City has been faced with wet years and floods alternating with episodes of drought. Average yearly precipitation in Mexico City is $846.1 \mathrm{~mm}$. It is relatively concentrated in one half of the year. Key climate related challenges include flooding due to heavy precipitation and flash floods, heat waves (combined with a heavily urbanized area), and drought and water scarcity. Groundwater extraction from the aquifer below the city is also leading to soil subsidence.

Rotterdam (The Netherlands) is a city of 0.6 million residents (city proper), with a temperate oceanic climate. The city is located in Western Europe, at the Rhine-Meuse-Scheldt river delta and North Sea coast. The city is located on river banks, polders, and reclaimed land, and much of the city is below sea level (up to $-6 \mathrm{~m}$ ). Rotterdam hosts one of the largest harbors in the world, and its economy is heavily dependent on the careful control of water. The city has longstanding experience and expertise regarding water management, and is currently pairing urban renewal with water sensitive and resilient adaptation (e.g., [23,62]). Specific water challenges include precipitation runoff in the low-lying polders due to more intense rain showers, and riverine and sea-based flooding in unembanked areas and flood risks in the polders. Average yearly precipitation in Rotterdam is $855.6 \mathrm{~mm}$, relatively spread out over the year. Key climate related challenges include flooding due to heavy precipitation, flood risks from sea and rivers, and heat waves (combined with a heavily urbanized area). Drought and soil subsidence are an issue, but less than in Mexico City, partly also because drinking water is extracted from the river rather than the aquifer. Drinking water scarcity is no issue.

The 'Water Squares' in Rotterdam were demonstration projects developed in the context of the Rotterdam Water City 2035 program, and the earlier Water Plan 2. The Benthemplein Water Square [63], completed in 2013, is the best-known, but several other squares have been developed. The squares core concept is that they are dry under regular conditions, and can be used as a public square, but can temporarily store rainwater during downpours. The squares are recessed (one or more aboveground basins) and connected to underground basins and sometimes groundwater infiltration devices. These provide buffer capacity, allowing rainwater from the square and surrounding buildings to be retained until the city sewage system can better handle the discharge. The water squares explicitly aim for multi-functional solutions, such as rainwater buffering, making water management more visible to the public (communication), and enhancing the quality of public space. Rotterdam and Mexico City have taken such squares as focal point in their collaboration. In Rotterdam, water squares have been developed to the north and to the west of the city center, and lessons learned from these early designs have been included in the Zoho Climate-Proof District (north of the center), which expands on the earlier designs with broader climate and social resilience efforts, such as explicit attention for community initiatives. All of these locations are highly urbanized areas, and slightly below sea level ( 0 to $-1 \mathrm{~m}$ ), protected by dikes. In Mexico City, proposals focused on the Iztapalapa district, a highly urbanized, low elevation area on the former lake bed of Lake Texcoco. For a detailed description of the design process in Mexico City, see [64,65]. See Figures 1 and 2 for locations of the water squares and climatic profiles of the Netherlands and Mexico. Supplementary Materials S3 contains further details on the climate in both cities. 

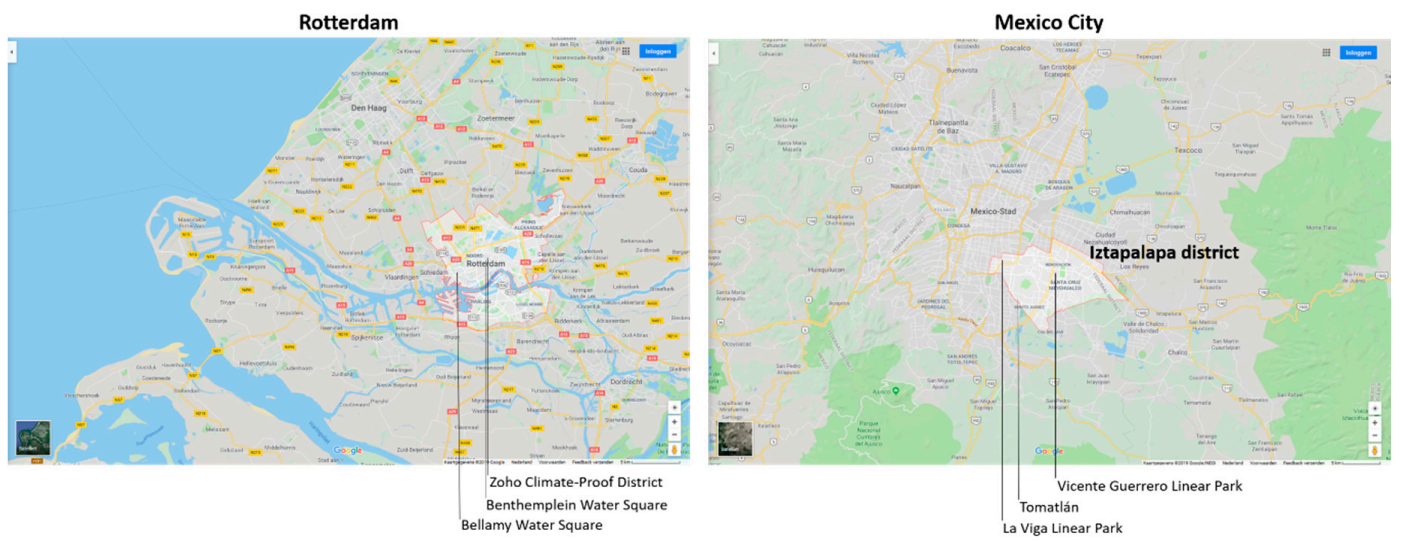

Figure 1. Locations of the water squares in Rotterdam (left) and proposed locations in Mexico City (right) (map source: Google Maps).
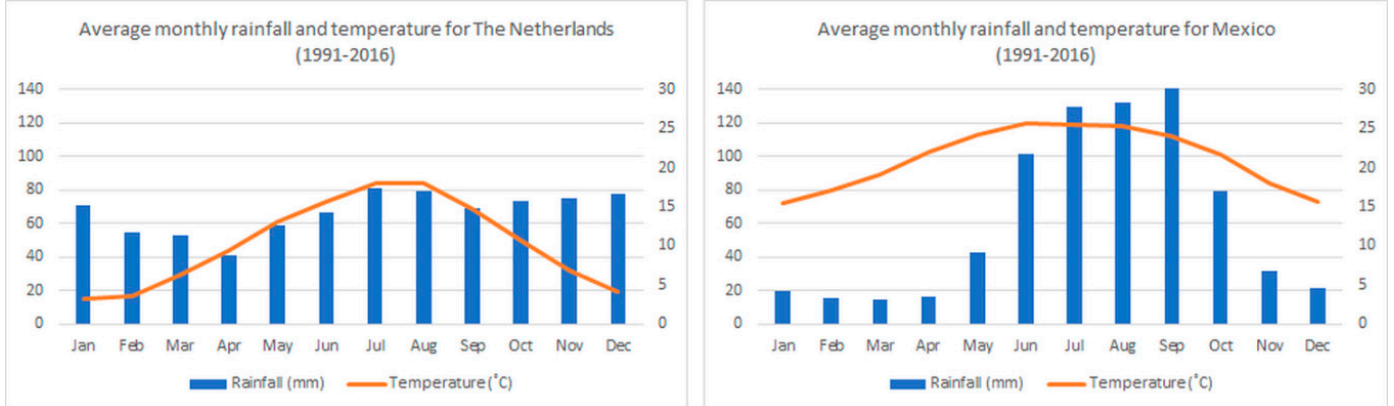

Figure 2. Temperature and precipitation profiles for the Netherlands (left) and Mexico (right) (data source: World Bank Climate Change Knowledge Portal; data from: CRU, University of East Anglia).

\subsection{Data Collection and Analysis}

To explore the actors and issues relevant to the case study, two helicopter interviews were conducted with the architectural firm that designed the water squares and with an international governmental organization involved in city-to-city knowledge transfer.

A first set of ten in-depth semi-structured interviews was conducted with actors in Mexico City, Rotterdam, and international organizations involved explicitly in the transfer of knowledge and policies concerning the water squares. These were focused interviews, exploring the specifics of the collaborations. A second set of ten semi-structured, but more open-ended interviews was held with various actors involved in the broader collaboration and knowledge exchange on water and resilience between the Netherlands and Mexico, including other water resilience projects. These interviews provided information on the local, national, and international context of the case study and potential barriers and stimuli that might and did arise. Interviews were transcribed, coded in nVivo, and qualitatively analyzed. An anonymized list of the interviews and the coding scheme can be found in the Supplementary Materials.

Other data was collected using site visits and participant observation. The first author was embedded in the Dutch embassy in Mexico, which is highly relevant because for the case of the water square this organization fulfilled the role of an 'innovation intermediary' [66]. The embassy played an important role in coordinating and facilitating knowledge exchange between Mexico City and Rotterdam. Specific project sites were visited to gain a good understanding of the local situation. Furthermore, the first author participated in local project meetings and workshops on the water square project as well as five other collaborative water resilience projects and events. As participant observer (cf. $[67,68]$ ), the researcher had a moderate to active level of participation in the resilience projects and could observe the collaboration, decision-making, and social interactions in this network at close hand and in-situ. Observations were recorded in a logbook and qualitatively analyzed. They provided 
valuable insight into the tacit aspects of city-to-city knowledge and policy exchange, such as social and cultural aspects, supplementing the more formal setting of individual interviews.

\subsection{Analytical Framework}

An empirical, in-situ analysis requires a process-based analytical framework, rather than a conceptual principle-based one. One challenge is that, as noted above, most literature on learning for resilience is prescriptive rather than empirical. Another challenge is that most sources focus on learning within communities and cities, not on learning between them. Orleans Reed et al. [5] do provide a process model for resilience learning in the context of the ACCCRN network. Steps include: gathering information and perspectives on hazards, socio-economic development and urban plans; vulnerability assessments; pilot projects and sector studies; developing a resilience strategy; city interventions; and learning from interventions, revisions, and further networking. However, this model also focuses on learning within cities ('shared learning' with local stakeholders), rather than knowledge and policy transfer between cities. Process frameworks like these are reminiscent of resilience analysis process methods (e.g., $[23,69,70])$, but with more focus on implementation design and testing, including pilots and strategy development. e.g., Wardekker et al. [70]: characterizing the system; characterizing the disturbances; inventorying options/plans; evaluating options/plans; follow-up analysis; and adjust plans/options and repeat if needed. Roughly, such frameworks contain an exploration/orientation phase on the context and issues, followed by inventory or design of pilots, options, plans or strategies (which may include implementing pilots or early measures), and an evaluation, testing, reflection, and refinement phase. While both in-city learning frameworks and general resilience assessment frameworks are relevant for city-to-city learning, they do not cover the full process of interaction that takes place between cities.

Contrasting this with the notions above, the framework would need to place more emphasis on the contact and interaction between cities (before detailed city-to-city subject-matter discussions and exchange take place) and the anchoring of the transferred knowledge (after the exchange of knowledge). Consequently, we have structured our analysis using a four-phased analytical model that describes different stages in the interaction and learning process between cities (see Figure 3 for an overview, elaboration per phase below).

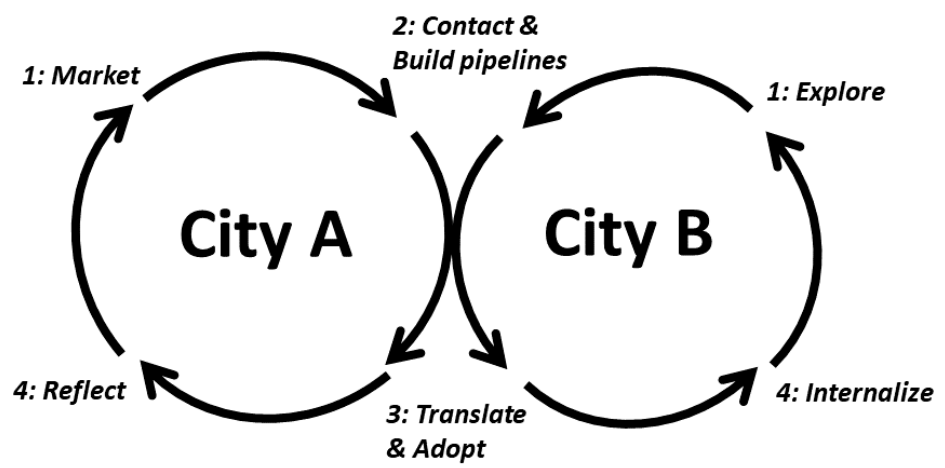

Figure 3. A circular model of the process of city-to-city knowledge transfer. City A imparts its knowledge on City B.

We start with the idea that communication channels for knowledge exchange can be purposely created to foster resilient urban development. Before these channels between knowledge providers and users can be constructed, urban actors need to become aware of their current knowledge resource and assess that is value based on comparison to others [2,5,71]. This includes critical reflection on the knowledge available, knowledge culture, local setting (institutions, regulations, history, ecology, geography, and socio-political dynamics), and physical water infrastructure in their own city and in other cities [28]. In reality not all other places can be assessed in the same way to see if they are 
viable candidates for knowledge exchange, and shortcuts are taken. Some actors are more adaptable than others in telling success stories and framing their city as a 'place of best practice' [51]. Notable examples include Copenhagen flaunting its expertise on cycling, Bogota peddling its knowledge on inclusive public transport across the globe and, most importantly for this paper, Rotterdam marketing its water know-how. Other cities are drawn to these cities and their best practice narrative in their exploration for policy relevant knowledge to reshape their urban environment in similar ways. We therefore refer to this first phase as the 'exploration and marketing phase', where knowledge providers in best-practice city A seek to market their knowledge and the knowledge users in city B seek to explore the wares that best-practice cities like A are selling.

Second, since the actors involved are anchored in different local settings, a concerted effort needs to be made by two cities to connect. The potential linkages dreamed up in phase 1 , through the marketing and exploration of knowledge stocks, need to be translated into real connections and formalized collaboration agendas. This solidifies the transfer channels between city A and city B. To make this happen city A and city B will need to reflect on each other's situations and develop mutual expectations [72]. They also need to consider the transfer, translation, or transformation of policy models [46]. Similar to regular strategic program development [29], we expect that developing a shared vision and securing long-term commitment will also be important for knowledge and policy transfer programs. It is important to note that different kinds of policy-relevant knowledge travel through these transfer channels-not only codified knowledge (such as text in manuals and guide books about alleged best practices in city A) but also tacit knowledge (experimental and practical insights embodied in the actors of city A not ready made to be implemented in city B). Elements of both tacit- and codified knowledge can be exchanged locally and globally when the 'local buzz' of vibrant information exchange and interactive learning within local milieus of city A links up with receptive local milieus in city $B$. Knowledge is embodied in actors and actors engage in the building of 'pipelines' to communicate and harness extra-local knowledge flows [71,73]. Therefore, we refer to this as the 'build pipelines phase'.

Third, the policy-relevant knowledge from city A, which has travelled along with the relevant actors through the solidified channels, needs to be implemented in city B. This is not simply a matter of taking a policy from one location and implementing it in another. Rather, it involves adapting it to a specific local context, practice and policy community, with a focus on the political process $[45,46,74]$. Local adaptive capacity, in general and of local institutions, is a relevant factor in this stage (cf. [75]). In other words, a process of translation takes place before adoption. The eventual adoption of this knowledge results in concrete changes into the material and intuitional fabric of city $\mathrm{B}$. We call this the 'translate and adopt' phase.

Fourth, looking back on this process over the previous phases, the hopeful expectation is that actors in city B-but also city A-have increased their knowledge pool and deepened their understanding of infrastructures and processes that foster urban resilience and that both are now more motivated and better equipped to transfer their knowledge to even more cities for the next round in the cycle. But equally important, the hope is also that this newfound knowledge is firmly anchored in material infrastructures and local practices of city B. Too often, unfortunately, experimental projects with innovative green infrastructure turn out to be isolated events that fade into oblivion without any effect on incumbent infrastructures and practices and the seemingly solid network connections that facilitated these projects might turn out to less robust when ties are not continually maintained or when a key individual is no longer part of a relevant organization [76,77]. To make this knowledge become robust, it is important that both cities 'reflect and internalize' the experiences in previous stages and to anchor these it in local practices and into vibrant and well-maintained knowledge transfer pipelines. We call this the 'reflect and internalize' phase. 


\section{Results}

In this section we will apply the four-phased analytical framework laid out above. For each of these four phases, we will interpret the events that took place, specifically examining water system variables such as the context, system, actors, processes, and structures [29]. This analysis sometimes also highlights the cognitive and institutional proximity or distance between the cities involved [78,79].

\subsection{Phase 1: Explore and Market}

The Dutch Embassy was setting up a project called Holland Branding to increase business opportunities for the Netherlands in Mexico. This long-term Holland Branding strategy is a tool for the embassy and Dutch business and knowledge institutions to materialize the opportunities into concrete projects. It started with brainstorm sessions within the Embassy and interviews with multiple companies and organizations located in Mexico City to understand the (current) reputation of The Netherlands. The end result was a plan for a shared vision on Holland Branding that was discussed with all the employees involved in the focus sectors of the embassy. Several observations could be made during this process.

First, according to the actors involved, it is important to understand the strengths and weaknesses of The Netherlands before it is possible to search for market opportunities in Mexico. A strength of The Netherlands is its water systems. The sinking of coastal lands has continually increased the Netherlands' vulnerability to floods and made it more difficult to discharge drainage water. However, the Dutch have been able to cope with these problems through the centuries by increasing their control over water flows. This they have achieved through collective action, often involving very many people [80].

Second, research was needed on the Mexican market. Attention was given to drivers for Mexico to set up new projects in the focus sectors. Regarding the water sector, these are mostly preventing floods, droughts and shortages of water. Besides the drivers for Mexico, it was necessary to set up the identity of the Netherlands, in other words, the Dutch approach. A SWOT analysis of the Netherlands in Mexico was made based on the information of the interviews to match the identity with the drivers of Mexico. The information was formulated in general messages and themes were set up, in which the focus sectors were combined for a cross-sectoral approach. In each of these themes urban resilience plays a role.

The cross-sectoral approach was also a focus point in the concept of the water square in Rotterdam. The engineers developed it to benefit public space and water management. The idea was to bring the water back into the city and keep the water local instead of drainage. This one local system created international interest. An organization in Mexico City noticed an article published on the water squares, while they were searching for a project that combined public space with sustainable water management.

'Given the vulnerability in terms of water in Mexico City, I thought that it would be interesting to integrate water but in a more responsible manner. So that is when I started with a research and that is why I was asking my colleague about a kind of project which mixed water management or responsible use of water on spaces...'

This quote showed that the organization knew what it needed to enhance its current systems. On the opposite side, Rotterdam was showing the strengths of their concept and uniqueness. The Dutch Embassy was setting up a more holistic approach to connect concepts like the water square with the market of Mexico. The focus on strength and weaknesses and connecting them is also highlighted by observations made by participants. They indicated that it is key to understand your own systems first.

'One of the key things is that each organization recognizes their strengths and their weaknesses. And when you understand which are your weaknesses then you understand that you need help on those weaknesses.' 
In short, before cities can search for complementary knowledge or market their knowledge they need to focus on their own systems. It is a time-consuming process to understand the strengths and weaknesses of a city's systems before marketing or exploring knowledge, namely research on the city's systems is necessary to form a framework of strengths and weaknesses. This is a step that leads to the possibility of building channels of communication to selected providers outside the local milieu to enhance knowledge.

\subsection{Phase 2: Build Pipelines}

Following the initial search and connection between the cities involved, broader contacts will need to be established between relevant actors in those cities. This contact will also need to be solidified into joint commitment towards the collaboration.

In case of the water squares, the process started when the Spatial Planning Office in Mexico City contacted the Dutch Embassy, late 2014, to explore interests and potential collaboration. A first meeting was held in February 2015 to discuss the knowledge that Mexico City was looking for in more detail. Following this meeting, the Embassy established contact between the Spatial Planning Office and the architectural firm that designed the water squares in Rotterdam. A series of phone and Skype calls followed, and a first face to face meeting was held in December 2015 in Mexico City with the Spatial Planning Office, Embassy, and architectural firm. This meeting helped to build trust, in the sense that the organizations established openness towards each other's views and willingness to cooperate. The actors shared ideas and established an agreement towards further collaboration (resp.9).

In February 2016 a workshop was organized to connect a wider base of key actors from both cities. The workshop was in the form of a round table discussion, with a more targeted focus on the potential of creating a multi-purpose water square project in Mexico City. This four-day "Water Workshop" gathered seven core actors, four Mexican and three Dutch (see Figure 4). During the first day, all actors gave presentations on their background, organization, and activities. Many participants left directly after the presentations, for unclear reasons. Only most Dutch participants, one participant of the Mexico City Resilience Office and two of the spatial planning agencies remained.

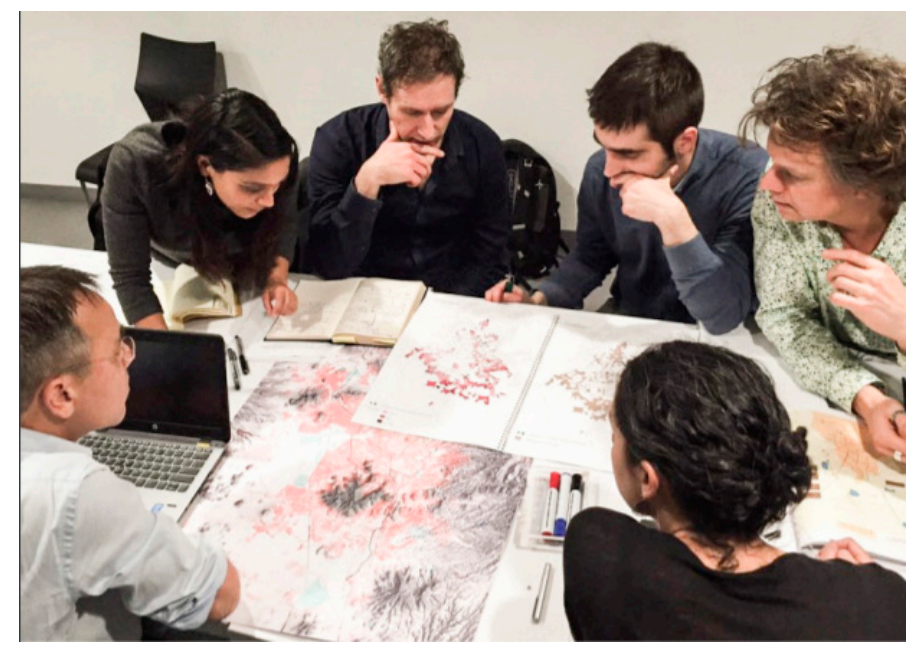

Figure 4. Impression of the water workshop in Mexico City (photo by: Víctor Manuel Rico Espínola) [64,65].

In the following two days, the Dutch participants attempted to gain further understanding of Mexico City by means of a more in-depth analysis of the city. The city was divided into five areas, each with its own environmental and social needs, and potential water-related solutions were explored using the 'CAPP Climate Adaptation App'. The information was then spatially structured and the potential and usefulness of water squares was explored per area. During the final day, this analysis was presented to the Mexican organizations, leading to further discussion. The effort and ideas presented 
were very well received and seemed to lead to an enhanced will to cooperate. Agreements were made on further steps, and the Dutch partners produced a report of the shared vision in collaboration with stakeholders.

Observations during the workshop and follow-up interviews suggested several factors that led to this success. First, the approach of exploring community needs per area in the city showed the Mexican participants that the Dutch were making a conscious effort at trying to understand their situation and specific needs, enhancing trust. This was important to overcome the cognitive distance between the participants due to the large geographical distance and differences, e.g., (resp.7):

"Knowledge from rich countries to poor countries does not translate easily. Because we have a very different political and cultural situation; we are in different stages. [ ... ] For example The Netherlands is very small and we have a lot of mountains. And then you get a lot of 'buts'. And it is not that it can't be done. It is just that it is so far away."

Second, the analysis was framed from the perspective of similarities between Rotterdam and Mexico City, revealing shared struggles and histories, rather than highlighting Rotterdam's accomplishments. Interviewees noted that this enhanced mutual understanding, as it highlighted mutual struggles with water, rather than implicitly suggesting superiority. As one interviewee described an experience with another country (resp. 7):

"So when I spoke, I said: We are very corrupt, just like you. And they were very happy to hear that, because that is an understanding. [... ] And I know that due to the Second World War, countries were very poor. However, when they come, they don't talk about how they were poor. They talk about how they are now the rich countries of the world."

In sum, for the second phase it was important to create a shared vision by involving a relatively broad set of key actors, more than just the linking-pin organizations. Some actors were less committed to the process initially. However, these differences were bridged by a strong effort by the visiting party and hosting linking-pin organizations to jointly explore the system and relevant context, i.e., the situation on the ground, the requirements for resilience and adaptation in different neighborhoods, and potential options. In addition, the geographic proximity was observed to be fairly low between the cities; one city a huge landlocked metropolis in a developing country and the other a medium-sized coastal city in a developed country. It was particularly valuable to highlight shared struggles between both cities to build trust and mutual understanding. This helped bridge the geographic distance and the willingness of all actors to collaborate, which enabled the actors to engage in building of 'pipelines' to communicate and harness extra local knowledge flows. As a result, the water squares became a potential lighthouse project.

\subsection{Phase 3: Translate and Adopt}

The agreements that were made in the first meetings, were written in a shared report. The intention was that this would lead to a joint project on water.

The differences in the organizations involved in the process provided some challenges. Particularly, the differences between the Dutch and Mexican government systems caused a lack of organizational proximity along with a cognitive distance between the actors. Much of the technical knowledge within the Dutch actors resided in privatized companies or (public or semi-public) knowledge institutions (Respondent 9). Dutch urban water management systems involve a number of different organizations that need to collaborate due to the spread of responsibilities and expertise, i.e., the government system is more decentralized. The Dutch government system is also known for the strong collaboration between different public and private actors (Observation 4). Mexican government organizations often involve a combination of technical and policy departments. For example, SACMEX is the water organization in Mexico City that contains governmental and technical knowledge. SACMEX, therefore, is almost independent and as a result more powerful and does not share its knowledge and expertise easily 
(Respondent 9). As a result, the organization was under less pressure to contribute to a collaborative project such as the water squares, and was difficult to reach by other participants during the process of designing them. Unlike the Dutch system, the Mexican government system is highly centralized.

A clear example of the challenges of the lack of organizational proximity presented itself when there was an unexpected change of director in the Mexican organization. Many new leaders are reluctant to continue with projects that started under the previous leadership due to the importance of personal image and reputation in Mexico. The important decision makers within the organization mostly change with a change of a governmental leader. Consequently, parties who are working together with the government need to set up new contacts all over again within the governmental organization. The combination of a centralized governance and changeable leadership makes it hard to set up projects that involve a longer time frame (Respondent 10).

However, in case of the water square, a local leader was directly involved in the organization supporting this project. The person actively promoted the project to the new director, and setup a meeting between the director and the Dutch Embassy to further emphasize the importance of the project and the Mexican-Dutch collaboration (Respondent 9). The report showcasing the water squares as a lighthouse project was completed and could help convince the new director. This showed that local leaders are necessary, both external to promote interaction with the communities and internal (within actors) to push the process within their organization.

The interviewees also elaborated on this need for local leaders for a successful implementation of an innovation. Local pressure is often needed to overcome obstacles, i.e., much practical progress comes from bottom-up initiatives. Local actors and communities are necessary to carry through on long-term, multi-purpose projects (Respondent 9, 10; Observation 4). As interviewees mentioned:

'So first we need to inform all these government agencies but at the same time we need to approach communities and we need to make sure to incorporate them into the design of the space. So in the end we learned that we design a process more than just a public space project or an architectural project.' (Respondent 6)

'And people, they create pressure. Awareness of the problem is also very important. If that is not there then it is very difficult to do something.' (Respondent 1)

'We have a strategy for that. What we are doing is, we are trying to establish a committee that is depended on the project. So we call people from the academy, and comparable important leaders and personalities and we are going to invite them to take part in this committee to keep this project alive for years to come.' (Respondent 5)

One of the challenges within the case was identified as the lack of organizational proximity that could negatively influence the policy learning and implementation of the water innovations. A lack of organizational proximity means that organizational flexibility will be required to tailor and adopt innovations [78]. Knowledge was also highly centralized, i.e., key experts from other organizations were not always available or left the office due to a change in leadership. This created a cognitive distance between the Mexican and Dutch actors that made it difficult for them to collaborate. These obstacles within the process show that city-to-city learning is not simply a matter of taking a policy from one location and implementing it in another. Rather, it involves adapting it to a specific local context, practice and policy community, with a focus on the political process $[45,46,74]$.

A secondary challenge, potentially reinforcing the former, was that few people involved were able to connect different disciplines. In Mexico City, there were many people who were highly educated and experienced in their specific discipline, but few people with an interdisciplinary focus (Respondent 1,2). Therefore, it proved difficult to translate the knowledge of individual disciplines towards interdisciplinary, multi-purpose projects, i.e., combining sector specific knowledge towards themes for projects (Observation 1). 
In sum, during the translation and adoption phase, we observed strong gaps in the organizational and cognitive proximity between the actors. Partly, this related to the different actors involved on both sides: primarily public for Mexico City; mixed public-private for Rotterdam. More important, however were differences related to the structures of the governance system, such as the institutional environment (e.g., modes of governance [81], styles of leadership, perspectives on fair governance) and the knowledge system (e.g., disciplinary-specialist versus interdisciplinary). Process-related differences played a role as well, such as the tendency of key decision-makers and experts to leave and organizational priorities and support for projects to shift strongly following a shift in leadership. The shared vision developed in phase two helped mediate these lacks in institutional and cognitive proximity. Key to overcoming the differences, however, was the presence and mobilization of local leaders, in the form of community leaders, broad societal committees that took ownership of the project, and leaders within key organizations that helped the project transition changes in leadership and kept parties on both sides activated.

\subsection{Phase 4: Internalize and Reflect}

The case of the water square is still in development and currently in phase three. In addition, the 100 Resilient Cities network reached its goal of a hundred cities in 2016 and the network is still developing (Respondent 3). So, unfortunately, there is not a lot of information on this phase yet. Nonetheless, it can be said that the intensity of the interaction between the cities decreases in this phase. Actors in Rotterdam will reflect on the whole process and incorporate the newly gained knowledge and experiences for the next round of knowledge transfer with another city. In its turn, actors in Mexico City need time to internalize the policy relevant knowledge that was transferred so that it can be incorporated in other systems of the city or be used in a next round of knowledge transfer with another city. In other words, both cities have increased their knowledge pool and deepened their understanding of infrastructures and processes that foster urban resilience. And both are now more motivated and better equipped to transfer their knowledge to even more cities for the next round in the cycle. Additionally, the increasing number of knowledge transfer rounds on urban resilience helps with defining the framework around the concept more precisely. Cities gain knowledge by experiencing more knowledge transfers on urban resilience. Both cities need to market the project, individually and together, to create new projects—new knowledge transfers—on the knowledge they gained. However, it can be expected that the highly centralized Mexican government system will influence the internalization process negatively due to organizational inflexibility. One interviewee already mentioned an aspect for progress that can be reached by reflecting on cases and implementing the new knowledge:

'It is totally important to exchange information and knowledge although it is also critical taking into account the particularities of each city. Even though the resilience initiative is of course a very remarkable international initiative, some people still think that it is still lacking precisely that adaptation layer so that the strategies make sense in each city. So it is a real challenge for the resilience strategy to come up with a toolkit that is really adaptable to the realities of each place.'

The quote shows that conceptual development is still highly needed in the field of resilience, in which networks can allow a faster learning experience due to knowledge transfers and combining the existing and new knowledge. The knowledge transfer model is a tool for supporting this process.

To summarize, several cultural, economic and geographical factors shaped the various phases of the city-to-city learning process between Rotterdam and Mexico City. To provide an overview of the dynamics discussed in this section, Figure 5 below present our empirical findings in terms of the four-phased analytical framework introduced in Section 2. 


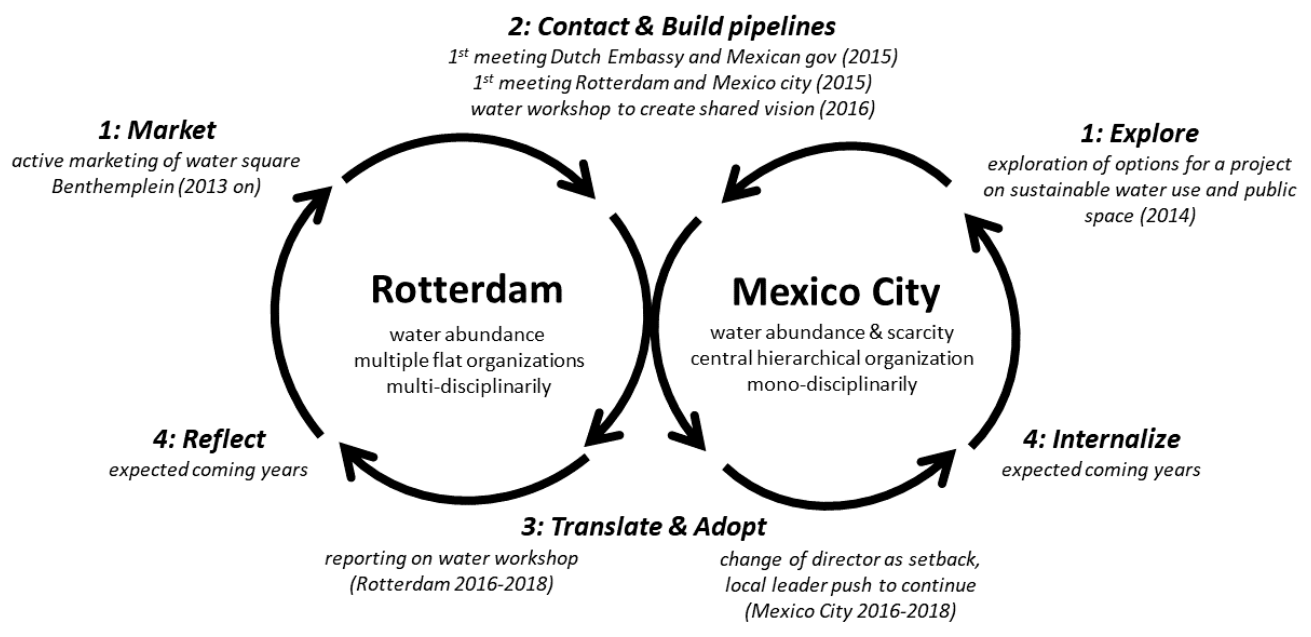

Figure 5. Representation of the process of city-to-city knowledge transfer between Rotterdam and Mexico City related to water squares.

\section{Discussion}

\subsection{City-To-City Learning for Urban Resilience}

The existing literature on learning for resilience is rather prescriptive and primarily focused on in-city learning. In contrast, our analysis is empirically descriptive and focused on city-to-city learning. This connotes a particular conceptualization of learning related to notions of organizational learning [82] and social learning [83]. Organizational learning can start in anticipation of ('front loop' learning) or reaction to ('back loop') disturbances. It can range from practical to more fundamental: from changing skills, routines and practices ('single loop' learning) to questioning and adjusting assumptions and policies ('double loop') to fundamental debate about values and norms ('triple loop') (e.g., $[5,57,82])$. Judging by the case study, city-to-city learning might help cities move from single loop learning, focused on fixing the errors in routines based on status quo thinking, to double loop learning. This holds particularly true in international urban resilience networks, and could be stimulated by actively exploring and comparing good (and less successful) practices in cities worldwide. Different cities will have a different take on how to adapt their water systems, providing novel ideas to other cities. In our case study, the idea of storing water in public space and using excess water and urban adaptation options to actively increase public spatial quality was a novel idea that provided an impetus for Mexico City to change their current approach. It may relate to triple loop learning as well, since it provides a different take on the value of public space. However, no explicit debate on underlying values was observed. In general, there may be a risk that policies and practices are taken up by a city based on novelty value, rather than an actual reflection on and matching with public values and norms.

More practically, the literature on learning for resilience discusses tools such as monitoring and experimentation, and the importance of broad participation of stakeholders in the learning process, the need for long-term collaborative learning that is able to withstand short-term politics, and the need for inclusion of multiple types of knowledge (e.g., in addition to formal scientific knowledge, also practical, tacit and experiential knowledge) and co-production of knowledge (e.g., [5,57,84-87]). The influence of power, politics, and institutional dynamics is also mentioned as a problematic aspect in social learning. In the Mexico City case, we could observe that many of the factors mentioned above were problematic. The stakeholders and even individuals involved in the learning process were a select group of mostly representatives of authorities and scientists, with only one Dutch private partner involved. There was no broader participation of citizens, NGOs and companies. The group involved was highly sensitive to the local institutional, political and power dynamics: the learning parties were those that were formally responsible, and the process was complicated by a shift in formal leadership in Mexico City, which risked removing key people—and with them the institutional memory—from office. Nonetheless, 
efforts were observed to anchor the knowledge through local leaders that were less vulnerable to such shifts in power and could help bridge the knowledge gained from the formal parties to other local actors. We would suggest that collaborative co-production, with attention for local power, political, and institutional dynamics, is a particularly sensitive and critical point in city-to-city learning. Formal city-to-city learning events such as local workshops and delegation visits easily result in a potentially vulnerable and technocratic form of learning rather than broader and well-anchored and internalized social learning. This calls for explicit attention in designing the city-to-city learning process.

In exploring the dynamics of city-to-learning we identified four phases. The first phase was described as the exploration and marketing of knowledge. It was initially expected that the main focus would be on the Rotterdam marketing existing knowledge of resilient systems by touting its pioneering water square and of Mexico City exploring by looking for best practice examples of innovative resilient systems around the world before stumbling on Rotterdam's example. In this conceptualization both transferring parties would be looking outward ('know the other'). However, this phase was much more introspective and to a large extent the actors tried to understand the strengths and weaknesses of their own city's systems during outreach ('know thyself'). This is in line with some of the work on Sustainability Transitions, which investigates how actors can break the lock-in of incumbent systems of water provision [88]. In particular with the approach of Transition Management, which stresses that a small group of agents who want to change the status quo needs to start with the introspective and mental work of developing shared conceptualizations and visions before linking up and build coalitions with other actors [89]. For instance, Ferguson et al. [29] use the Transition Management approach to develop a diagnostic framework to facilitate transformative change in urban water systems, which stresses the need for these kinds of introspective efforts by the actors in the early stages. For the second and third phase, we found that the differences in geographical and institutional environment in Mexico City turned a seemingly clear-cut one-directional transfer much more challenging endeavor. Successful transfer, then, is a two-way street not only in the in the sense that the transferring party also takes relevant knowledge back, but also in the sense that it requires alignment of the knowledge base between the two parties. This took place in the second phase, where we observed a conscious framing and reframing of the history, socio-political-cultural contexts, and challenges in each city. Participants attempted to rephrase their own positions in terms of that of the other, to match each other's situation in many aspects. This serves to better align the two cities. It should provide sufficient 'sameness' (cf. [90]) to establish mutual understanding and build trust - to argue that both cities' experiences and goals are sufficiently aligned to be a meaningful partner. Yet, there needs to be sufficient 'difference' as well [90], in order to highlight specific aspects in which the cities can learn something from the other. Ideally, this process also takes into account different framing of what urban resilience means, because different cities and different actors within a city can have very different approaches to resilience, leading to very different implementations into policies and practical interventions [91]. In the third phase, such further translation into practical policy projects (e.g., new policy designs or white papers, or pilot projects and interventions) is made. During this practical experimentation and implementation, learning can take multiple forms: technical, formal (hard data, e.g., documents, projects, official authorities) and informal (soft data, e.g., implicit/tacit knowledge, professional and social networks) (cf. [44,50]). In the context of a single tangible project, much broader policy-relevant knowledge can be said to 'hitch a ride'. For instance, Dutch ideas about interdisciplinary approaches and a less rigid and hierarchical institutional organization of the water sector also reached Mexican ears. The Dutch in turn might have appreciated the technical expertise available in the Mexican government organizations (which is quite often outsourced in Dutch governments). In another way broader policy-relevant can be said to be encapsulated within the tangible artefact of a single project. For instance, a water square doubles as a buffer in a large technical system and as a way to create vibrant public space, which makes the actors involved rethink the single-purpose and efficiency logic of urban infrastructure. Similarly, the local leaders recruited in the process serve both as a source of redundancy or omnivory for the knowledge learned, and as a source of polycentricity that facilitates alignment of the values and goals 
for resilience-building between authorities and communities and citizens. This can in turn be used to stimulate a broader social learning process (cf. [92]). As for the fourth phase, at the time of our analysis the process has not yet progressed to this stage. As we showed, actors can reflect on the process and internalize part of the lessons during earlier phases. It would be valuable to conduct an ex-post analysis once there is 'closure' around the project and its associated activities. Particularly, it would be interesting to analyze if the water square project has engendered changes broader institutions and organizational routines. It would also be interesting to see whether the actors involved can be enrolled as advocates for the further spread of water squares or if they have to some extent become disillusioned with this idea. Similarly, many other aspects might have strengthened, including the ability to work across disciplinary boundaries, the strength of knowledge networks, and the ability to better align and anchor resilience-building with the interests of local communities.

\subsection{Avenues for Further Research}

Our analysis city-to-city learning zoomed in on the transfer dynamics in case of one tangible project. The pioneering water square in Rotterdam, which was to be transplanted to Mexico City, is best conceived of as a single 'socio-technical experiment' — defined as a "practice-based and challenge-led initiative, which is designed to promote system innovation through social learning" [93]. The literature on socio-technical experiments suggests that individual projects in and of themselves are not enough to change the underlying principles of the broader water system, but that they are a key unit of analysis and that their wider learning and demonstration effects do provide a crucial starting point for such a transition [93]. Furthermore, for both the actors involved in the transfer and for us as academics, in conceptualizing this process the advantage of providing center stage to individual experiments such as water squares is that it provides a very tangible precursor and a of clear sense of direction. Another way to get to the essence of city-to-city learning would be to look at larger collections of projects and at broader processes of translation of policy-relevant knowledge. Whilst we believe that our approach of describing one concrete project as a vessel for policy translation as a way to study has certain important merits, we certainty recognize that this would be a worthy agenda for future research.

One consideration for expanding the research on city-to-city learning for urban resilience is the potential impact of situational factors and the progression of projects over time. Policy transfer risks resulting in policy failure, if the transfer does not take into account these situational differences (e.g., [94]). Geographic factors can influence the success or shape that projects take in a city. Rotterdam and Mexico City experience similar amounts of yearly precipitation and both developed water squares in low elevation locations that function as a 'bathtub'. However, Rotterdam's precipitation is relatively spread out over the years compared to Mexico City, and Mexico City has hills that drain into the valley as well. Drought and water scarcity are also much more an issue in Mexico City. Consequently, the shape that water squares take will likely differ. Rotterdam's are designed to drain on the main water system within days, while Mexico's squares might focus on retaining water for a longer period. Cultural factors can also play an important role. As discussed above, Mexico City has a culture of strong leadership, disciplinary expertise and concentration of expertise into a single management organization, whereas Rotterdam is more focused on collaboration, interdisciplinarity, and an ecosystem of multiple organizations with different expertise. Cultural factors are important in learning processes and transfer of policy proposals, but often difficult to pinpoint within and between cases. As the case showed, however, successful learning can take place when such factors are taken into account. Political factors are also highly important. Research in the Dutch context showed that the political interest of local aldermen and councilors is of key importance for the success of local adaptation [95], and the Mexican case in this paper showed similar processes, where leadership changes could strongly impact specific projects when the previous leader strongly identified with a project. Socio-economic factors are also important. Actors might push for very different locations and implementations of water squares, to strongly diverging effects. One risk of any pilot project, for example, might be that it becomes a prestige project that might be implemented in high visibility locations, such as tourist centers, 
business centers or richer neighborhoods, whereas they might be most needed in high density poorer neighborhoods. Similarly, governments might opt for high-tech implementations that involve the city's strategic business partners, potentially neglecting higher maintenance costs or the wishes of the neighborhoods in which projects are implemented. Rotterdam's first attempt at constructing a water square failed due to similar reasons: connections with that neighborhood were poor and the square was not accepted by the population. In next iterations, co-design with residents was a key point, leading to successful projects. In the case of Mexico City, the efforts to establish water squares has however specifically and intentionally focused on a poorer district, in the realization that such squares can also improve the spatial and social quality of the district [64,65]. In Rotterdam, the squares are also located in poorer areas. Such situational factors could impact the successful implementation of water squares, but could also determine their long term survival. For example, high-tech options might involve pumps and filtration systems that could be vulnerable to failures, neglect of maintenance (e.g., during periods of austerity), or debris and waste in runoff that enters the square. More low-tech and community-involved projects on the other hand could run the risk of deterioration when attention and community interest fade. Little is currently known of such long term survival factors for water squares and similar urban pilots and experiments, and this should be further investigated.

Another interesting point for future research would be to see if the four phases described here can also be identified in other cases studies of city-to-city learning or urban policy translation and whether describing these findings accordingly leads to productive insights. Attempts to do this could focus on other cases studies in water resilient cities or other related efforts. For instance, it would be interesting to compare actor coalitions and strategies of city-to-city learning in urban water projects with a 'resilient city' focus with those that are framed as contributing achieving 'smart city'. It would also be interesting to compare policy translation learning in the context of resilient water systems with resilient waste management or transportation systems. At least conceptually, there is nothing inherent in our four-phase framework that would limit the application to a focus on resilience or to the water domain.

\section{Conclusions}

We presented a policy practice analysis of the city-to-city exchange of policy relevant knowledge for building urban water resilience between two cities that are currently highly active on this topic: Mexico City and Rotterdam. Mexico City faces numerous water-related challenges and expects increasing pressure due to climate change [96]. Rotterdam is a city with well-known for its water expertise and experience. It is an often-used example of Dutch delta planning approaches, taken as 'good practice' in water management and climate adaptation worldwide [90,97]. Learning is seen as a key principle in resilience-building and cities worldwide are actively pursuing knowledge exchange through experimentation and collaboration with consultants, architects, and academics in bilateral or transnational networks. Many cities face urgent and worsening challenges today while public budgets are under pressure as they navigate through these slow and costly learning processes. Moreover, strong differences exist in the institutional, geographic, and cultural context of cities, which might limit the possibilities for knowledge and policy transfer. The analysis in this paper provided several lessons on barriers and stimuli for successful city-to-city learning in the context of water systems and urban resilience. To present these findings we mobilized a framework composed of four distinct phases.

During the first phase of the city-to-city knowledge transfer (exploration and marketing), a key success factor was that both cities did not start with an external search for sources or potential recipients of knowledge. Rather, they started with introspection. It was important to have clear picture of one's own systemic strengths and weaknesses, for both cities involved. This introspection helped the search for complementary partner cities, and it may also provide sufficient self-awareness and material for the reframing needed in phase 2 .

In the second phase (building pipelines), it was important to create a mutual understanding of struggles and histories, to overcome geographical and cultural differences. Creating a shared vision 
helped reduce misunderstandings in the process. It appeared particularly critical to heavily negotiate and reiteratively reframe one's own and each other's reality. The perceived situation of both cities needed to be both similar (to build trust and develop a shared vision) and different (to have something to offer to the other; to provide something that could be learned). This process also served to establish the cities as equal partners, rather than a mentor-mentee relationship which can be a detrimental framing for leaning [98]. While negotiation and reframing are normal in multi-actor settings, the tension between matching and differing in framing and situation is very high in city-to-city learning and warrants further research.

For the third phase (translation and adoption) we observed that differences in the institutional environment (e.g., modes of governance, level of interdisciplinarity) could hamper the implementation of 'imported' ideas. These barriers were reduced by recruiting strong local leaders, external to the official organizations, into the process. This required organizational flexibility of the official organizations. However, they pursued this course because it would also reduce the risk of losing institutional memory, which was high during leadership changes in the centralized, hierarchical organizations involved. Anchoring through local leaders provided some redundancy or omnivory in the knowledge system. These issues relate to resilience principles not necessarily associated with learning: in this (and the next) phase, the new knowledge and the local knowledge system themselves are made resilient.

In the fourth phase, which follows the actual exchange, cities will need to internalize the lessons and resilience thinking in general (internalization and reflection) so that this can be applied in other projects. This applies to lessons regarding resilience-building, but also to the learning process itself. Particularly pronounced lessons for city-to-city learning seem to be that the starting phases and their introspection and reframing processes are critical, and that in the later phases it is important to make the knowledge itself resilient by building internal and external networks. By internalizing such lessons, cities might strengthen not only their own resilience, but also enhance future exchanges with other cities.

Supplementary Materials: The following are available online at http://www.mdpi.com/2073-4441/11/5/983/s1, Document S1: List of interviews, Document S2: Coding scheme, Document S3: Temperature and precipitation profiles for Rotterdam and Mexico City.

Author Contributions: Conceptualization, S.I., F.S. and A.W.; Data curation, S.I.; Formal analysis, S.I., F.S., and A.W.; Investigation, S.I.; Methodology, S.I., F.S. and A.W.; Supervision, F.S. and A.W.; Validation, S.I.; Writing - original draft, S.I., F.S. and A.W.; Writing-review and editing, F.S. and A.W.

Funding: This research received no external funding.

Acknowledgments: We thank the Netherlands Embassy to Mexico for hosting one of the researchers for the duration of the study and we thank various practitioners throughout Mexico and the Netherlands for their time and effort to share their insights on the dynamics of knowledge exchange on urban resilience and water squares.

Conflicts of Interest: The authors declare no conflict of interest.

\section{References}

1. UN. World Urbanization Prospects: The 2014 Revision; Department of Economic and Social Affairs, United Nations: New York, NY, USA, 2014.

2. Knight, R.V. Knowledge-based development: Policy and planning implications for cities. Urban Stud. 1995, 32, 225-260. [CrossRef]

3. Gordon, I.; McCann, P. Innovation, agglomeration and regional development. J. Econ. Geogr. 2005, 5, 523-543. [CrossRef]

4. McGranahan, G.; Balk, D.; Anderson, B. The rising tide: Assessing the risks of climate change and human settlements in low elevation coastal zones. Environ. Urban. 2007, 19, 17-37. [CrossRef]

5. Orleans Reed, S.; Friend, R.; Toan, V.C.; Thinphanga, P.; Sutarto, R.; Singh, D. Shared learning for building urban climate resilience: Experiences from Asian cities. Environ. Urban. 2013, 25, 393-412. [CrossRef]

6. Capela Lourenço, T.; Rovisco, A.; Groot, A.; Nilson, C.; Füssel, H.M.; Van Bree, L.; Street, R.B. Adapting to an Uncertain Climate: Lessons from Practice; Springer: Cham, Switzerland, 2014. 
7. Markard, J.; Raven, R.; Truffer, B. Sustainability transitions: An emerging field of research and its prospects. Res. Policy 2012, 41, 955-967. [CrossRef]

8. UN. Transforming our World: The 2030 Agenda for Sustainable Development; United Nations: New York, NY, USA, 2015.

9. UN. Habitat III: The New Urban Agenda; United Nations: New York, NY, USA, 2016.

10. Collier, M.J.; Nedović-Budić, Z.; Aerts, J.; Connop, S.; Foley, D.; Foley, K.; Newport, D.; McQuaid, S.; Slaev, A.; Verburg, P. Transitioning to resilience and sustainability in urban communities. Cities 2013, 31, S21-S28. [CrossRef]

11. De Jong, M.; Joss, S.; Schraven, D.; Zhan, C.; Weijnen, M. Sustainable-smart-resilient-low carbon-eco-knowledge cities; making sense of a multitude of concepts promoting sustainable urbanization. J. Clean. Prod. 2015, 109, 25-38. [CrossRef]

12. Leichenko, R. Climate change and urban resilience. Curr. Opin. Environ. Sustain. 2011, 3, 164-168. [CrossRef]

13. Linkov, I.; Bridges, T.; Creutzig, F.; Decker, J.; Fox-Lent, C.; Kröger, W.; Lambert, J.H.; Levermann, A.; Montreuil, B.; Nathwani, J.; et al. Changing the resilience paradigm. Nat. Clim. Chang. 2014, 4, 407-409. [CrossRef]

14. Alberti, M.; Marzluff, J.M. Ecological resilience in urban ecosystems: Linking urban patterns to human and ecological functions. Urban Ecosyst. 2004, 7, 241-265. [CrossRef]

15. Schewenius, M.; McPhearson, T.; Elmqvist, T. Opportunities for increasing resilience and sustainability of urban social-ecological systems: Insights from the URBES and the cities and biodiversity outlook projects. AMBIO 2014, 43, 434-444. [CrossRef] [PubMed]

16. Zevenbergen, C.; Veerbeek, W.; Gersonius, B.; Van Herk, S. Challenges in urban flood management: Travelling across spatial and temporal scales. J. Flood Risk Manag. 2008, 81-88. [CrossRef]

17. Godschalk, D.R. Urban hazard mitigation: Creating resilient cities. Nat. Hazards Rev. 2003, 4, $136-143$. [CrossRef]

18. Douglas, M. From global intercity competition to cooperation for livable cities and economic resilience in Pacific Asia. Environ. Urban. 2002, 14, 53-68. [CrossRef]

19. Rijke, J.; Farrelly, M.; Brown, R.; Zevenbergen, C. Configuring transformative governance to enhance resilient urban water systems. Environ. Sci. Policy 2013, 25, 62-72. [CrossRef]

20. Eraydin, A.; Taşan-Kok, T. Resilience Thinking in Urban Planning; Springer: Dordrecht, The Netherlands, 2013.

21. Jabareen, Y. Planning the resilient city: Concepts and strategies for coping with climate change and environmental risk. Cities 2013, 31, 220-229. [CrossRef]

22. Deppisch, S. Resilience Thinking as Leitmotif in Urban and Regional Planning Dealing with Climate Change Impacts. In Urban Regions Now E Tomorrow: Between Vulnerability, Resilience and Transformation; Springer Nature: Wiesbaden, Germany, 2017; pp. 165-188.

23. Wardekker, J.A.; De Jong, A.; Knoop, J.M.; Van der Sluijs, J.P. Operationalising a resilience approach to adapting an urban delta to uncertain climate changes. Technol. Forecast. Soc. Chang. 2010, 77, 987-998. [CrossRef]

24. Ernstson, H.; Van der Leeuw, S.E.; Redman, C.L.; Meffert, D.J.; Davis, G.; Alfsen, C.; Elmqvist, T. Urban transitions: On urban resilience and human-dominated ecosystems. AMBIO 2010, 39, 531-545. [CrossRef] [PubMed]

25. Davoudi, S.; Brooks, E.; Mehmood, A. Evolutionary resilience and strategies for climate adaptation. Plan. Pract. Res. 2013, 28, 307-322. [CrossRef]

26. Berbés-Blázquez, M.; Mitchell, C.L.; Burch, S.L.; Wandel, J. Understanding climate change and resilience: Assessing strengths and opportunities for adaptation in the Global South. Clim. Chang. 2017, 141, 227-241. [CrossRef]

27. Olazabal, M. Resilience, Sustainability and Transformability of Cities as Complex Adaptive Systems. In Urban Regions Now \& Tomorrow: Between Vulnerability, Resilience and Transformation; Springer Nature: Wiesbaden, Germany, 2017; pp. 73-97.

28. Brown, R.R.; Keath, N.; Wong, T.H. Urban water management in cities: Historical, current and future regimes. Water Sci. Technol. 2009, 59, 847-855. [CrossRef] [PubMed]

29. Ferguson, B.C.; Brown, R.R.; Deletic, A. Diagnosing transformative change in urban water systems: Theories and frameworks. Glob. Environ. Chang. 2013, 23, 264-280. [CrossRef] 
30. Folke, C.; Hahn, T.; Olsson, P.; Norberg, J. Adaptive Governance of Social-Ecological Systems. Annu. Rev. Environ. Resour. 2005, 30, 441-473. [CrossRef]

31. da Silva, J.; Morera, B. City Resilience Framework; Arup \& Rockefeller Foundation: London, UK; New York, NY, USA, 2014; Available online: http://publications.arup.com/Publications/C/City_Resilience_Framework.aspx (accessed on 6 April 2019).

32. Koop, S.H.; Van Leeuwen, C.J. Assessment of the sustainability of water resources management: A critical review of the city blueprint approach. Water Resour. Manag. 2015, 29, 5649-5670. [CrossRef]

33. Meerow, S.; Newell, J.P. Urban resilience for whom, what, when, where, and why? Urban Geogr. 2016. [CrossRef]

34. Wardekker, A. Resilience principles as a tool for exploring options for urban resilience. Solutions $2018,9$. Available online: https://www.thesolutionsjournal.com/article/resilience-principles-tool-exploring-optionsurban-resilience/ (accessed on 6 April 2019).

35. Šakić Trogrlić, R.; Rijke, J.; Dolman, N.; Zevenbergen, C. Rebuild by design in Hoboken: A design competition as a means for achieving flood resilience of urban areas through the implementation of green infrastructure. Water 2018, 10, 553. [CrossRef]

36. Brown, C.; Shaker, R.R.; Das, R. A review of approaches for monitoring and evaluation of urban climate resilience initiatives. Environ. Dev. Sustain. 2018, 20, 23-40. [CrossRef]

37. Chelleri, L.; Waters, J.J.; Olazabal, M.; Minucci, G. Resilience trade-offs: Addressing multiple scales and temporal aspects of urban resilience. Environ. Urban. 2015, 27, 181-198. [CrossRef]

38. Wardekker, A.; Wilk, B.; Brown, V.; Uittenbroek, C.; Mees, H.; Driessen, P.; Wassen, M.; Molenaar, A.; Walda, J.; Runhaar, H. A diagnostic tool for supporting policymaking on urban resilience. Cities. (under review).

39. Wilk, B. Translating the Scientific Concepts of Resilience into a Diagnostic Tool for Urban Climate Resilience Building. Master's Thesis, Utrecht University, Utrecht, The Netherlands, November 2016.

40. Keiner, M.; Kim, A. Transnational city networks for sustainability. Eur. Plan. Stud. 2007, 15, 1369-1395. [CrossRef]

41. Betsill, M.M.; Bulkeley, H. Transnational networks and global environmental governance: The Cities for Climate Protection program. Int. Stud. Q. 2004, 48, 471-493. [CrossRef]

42. Betsill, M.M.; Bulkeley, H. Cities and the multilevel governance of global climate change. Glob. Gov. 2006, 12, 141-159. [CrossRef]

43. Bulkeley, H. Reconfiguring environmental governance: Towards a politics of scales and networks. Polit. Geogr. 2005, 24, 875-902. [CrossRef]

44. Bontenbal, M.; Van Lindert, P. Transnational city-to-city cooperation: Issues arising from theory and practice. Habitat Int. 2009, 33, 131-133. [CrossRef]

45. Van Ewijk, E.; Baud, I.; Bontenbal, M.; Hordijk, M.; van Lindert, P.; Nijenhuis, G.; van Westen, G. Capacity development or new learning spaces through municipal international cooperation: Policy mobility at work? Urban Stud. 2015, 52, 756-774. [CrossRef]

46. McCann, E. Urban policy mobilities and global circuits of knowledge: Toward a research agenda. Ann. Assoc. Am. Geogr. 2011, 101, 107-130. [CrossRef]

47. Seymoar, N.K.; Mullard, Z.; Winstanley, M. City to City Learning; International Centre for Sustainable Communities: Vancouver, BC, Canada, 2009.

48. UNESCO-IHE. City-to-City Learning for Disaster Resilience: Towards Secure, Sustainable and Vibrant Cities; UNESCO-IHE: Delft, The Netherlands, 2016; Available online: https://www.un-ihe.org/sites/default/files/ city_to_city_flyer_vs200516.pdf (accessed on 6 April 2019).

49. Biggs, R.; Schlüter, M.; Schoon, M.L. Principles for Building Resilience: Sustaining Ecosystem Services in Social-Ecological Systems; Cambridge University Press: Cambridge, UK, 2015.

50. Campbell, T. Learning cities: Knowledge, capacity and competitiveness. Habitat Int. 2009, 33, $195-201$. [CrossRef]

51. Sengers, F; Raven, R. Toward a spatial perspective on niche development: The case of Bus Rapid Transit. Environ. Innov. Soc. Transit. 2015, 17, 166-182. [CrossRef]

52. Bahadur, A.V.; Thornton, H. Analysing urban resilience: A reality check for a fledgling canon. Int. J. Urban Sustain. Dev. 2015, 17, 196-212. [CrossRef]

53. Mills, A.J.; Durepos, G.; Wiebe, E. Encyclopedia of Case Study Research; SAGE Publications: Thousand Oaks, CA, USA, 2010. 
54. Yin, R.K. Case Study Research: Design and Methods; SAGE Publications: Thousand Oaks, CA, USA, 2013.

55. Carpenter, S.; Walker, B.; Anderies, J.M.; Abel, N. From metaphor to measurement: Resilience of what to what? Ecosystems 2001, 4, 765-781. [CrossRef]

56. Folke, C.; Colding, J.; Berkes, F. Synthesis: Building Resilience and Adaptive Capacity in Social-Ecological Systems. In Navigating Social-Ecological Systems: Building Resilience for Complexity and Change; Cambridge University Press: Cambridge, UK, 2003; pp. 352-387.

57. Biggs, R.; Schlüter, M.; Biggs, D.; Bohensky, E.L.; BurnSilver, S.; Cundill, G.; Dakos, V.; Daw, T.M.; Evans, L.S.; Kotschy, K.; et al. Toward principles for enhancing the resilience of ecosystem services. Annu. Rev. Environ. Resour. 2012, 37, 421-448. [CrossRef]

58. Tyler, S.; Moench, M. A framework for urban climate resilience. Clim. Dev. 2012, 4, 311-326. [CrossRef]

59. CDMX. CDMX Resilience Strategy: Adaptive, Inclusive and Equitable Transformation; Ciudad de México (CDMX): Mexico City, Mexico, 2016; Available online: http://www.data.sedema.cdmx.gob.mx/resiliencia/descargar. html (accessed on 6 April 2019).

60. Gemeente Rotterdam. Rotterdam Resilience Strategy: Ready for the 21st Century; Gemeente Rotterdam, Rotterdam, The Netherlands, 2016; Available online: https://www.resilientrotterdam.nl/download (accessed on 6 April 2019).

61. Lankao, P.R. Water in Mexico City: What will climate change bring to its history of water-related hazards and vulnerabilities? Environ. Urban. 2010, 22, 157-178. [CrossRef]

62. De Graaf, R.; Van der Brugge, R. Transforming water infrastructure by linking water management and urban renewal in Rotterdam. Technol. Forecast. Soc. Chang. 2010, 77, 1282-1291. [CrossRef]

63. De Urbanisten. Water Square Benthemplein. Available online: http://www.urbanisten.nl/wp/?portfolio= waterplein-benthemplein (accessed on 8 April 2019).

64. Boer, F.; Salinas, E.M.; Van de Pas, B.; Rico Espínola, V.M. Hacia una Ciudad de México Sensible al Agua-Towards a Water Sensitive Mexico City; De Urbanisten, Deltares \& Autoridad del Espacio Público: Rotterdam, The Netherlands; Mexico City, Mexico, 2016. Available online: http://www.urbanisten.nl/wp/?portfolio=towardsa-water-sensitive-MexicoCity (accessed on 6 April 2019).

65. Salinas, E.M.; Boer, F.; Van de Pas, B.; Rico Espínola, V.M. Towards a Water Sensitive Mexico City; De Urbanisten: Rotterdam, The Netherlands, 2016; Available online: https:/www.deltares.nl/app/uploads/2018/01/20160629_ WS-CDMX_final-version-report-smsize.pdf (accessed on 6 April 2019).

66. Howells, J. Intermediation and the role of intermediaries in innovation. Res. Policy 2006, 35, 715-728. [CrossRef]

67. Pearsall, M. Participant observation as role and method in behavioral research. Nurs. Res. 1965, 14, 37-41. [CrossRef]

68. Spradley, J.P. Participant Observation; Holt, Rinehart \& Winston: New York, NY, USA, 1980.

69. Resilience Alliance. Assessing Resilience in Social-Ecological Systems: Workbook for Practitioners; Version 2.0; Resilience Alliance: Wolfville, NS, Canada, 2010.

70. Wardekker, J.A.; Wildschut, D.; Stemberger, S.; Van der Sluijs, J.P. Screening regional management options for their impact on climate resilience: An approach and case study in the Venen-Vechtstreek wetlands in the Netherlands. SpringerPlus 2016, 5, 750. [CrossRef]

71. Bathelt, H.; Malmberg, A.; Maskell, P. Clusters and knowledge: Local buzz, global pipelines and the process of knowledge creation. Prog. Hum. Geogr. 2004, 28, 31-56. [CrossRef]

72. Trompenaars, F. Riding the Waves of Culture; Nicholas Brealey Publishing: London, UK, 1993.

73. Owen-Smith, J.; Powell, W.W. Knowledge networks as channels and conduits: The effects of spillovers in the Boston biotechnology community. Organ. Sci. 2004, 15, 5-21. [CrossRef]

74. Stone, D. Learning lessons and transferring policy across time, space and disciplines. Politics 1999, 19, 51-59. [CrossRef]

75. Gupta, J.; Termeer, C.; Klostermann, J.; Meijerink, S.; Van den Brink, M.; Jong, P.; Nooteboom, S.; Bergsma, E. The adaptive capacity wheel: A method to assess the inherent characteristics of institutions to enable the adaptive capacity of society. Environ. Sci. Policy 2010, 13, 459-471. [CrossRef]

76. Hoogma, R.; Kemp, R.; Schot, J.; Truffer, B. Experimenting for Sustainable Transport: The Approach of Strategic Niche Management; Routledge: London, UK, 2005.

77. Schot, J.; Geels, F.W. Strategic niche management and sustainable innovation journeys: Theory, findings, research agenda, and policy. Technol. Anal. Strat. Manag. 2008, 20, 537-554. [CrossRef] 
78. Boschma, R. Proximity and innovation: A critical assessment. Reg. Stud. 2005, 39, 61-64. [CrossRef]

79. Boschma, R.; Frenken, K. The Spatial Evolution of Innovation Networks. A Proximity Perspective. In The Handbook of Evolutionary Economic Geography; Edward Elgar: London, UK, 2010; pp. 120-135.

80. Kaijser, A. System building from below: Institutional change in Dutch water control systems. Technol. Cult. 2002, 43, 521-548. [CrossRef]

81. Driessen, P.; Dieperink, C.; van Laerhoven, F.; Runhaar, H.; Vermeulen, W. Towards a conceptual framework for the study of shifts in modes of environmental governance: Experiences from the Netherlands. Environ. Policy Gov. 2012, 22, 143-160. [CrossRef]

82. Argyris, C.; Schön, D. Organizational Learning: A Theory of Action Perspective; Addison-Wesley: Boston, MA, USA, 1978.

83. Bandura, A. Social Learning Theory; Prentice-Hall: Englewood Cliffs, NJ, USA, 1977.

84. Kolb, D. Experiential Learning: Experience as the Source of Learning and Development; Prentice Hall: Englewood Cliffs, NJ, USA, 1984.

85. Cundill, G.; Fabricius, C. Monitoring in adaptive co-management: Toward a learning based approach. J. Environ. Manag. 2009, 90, 3205-3211. [CrossRef] [PubMed]

86. Bremer, S.; Wardekker, A.; Dessai, S.; Sobolowski, S.; Slaattelid, R.; Van der Sluijs, J. Toward a multi-faceted conception of co-production of climate services. Clim. Serv. 2019, 13, 42-50. [CrossRef]

87. Hegger, D.L.T.; Dieperink, C. Joint knowledge production for climate change adaptation: What is in it for science? Ecol. Soc. 2015, 20, 1. [CrossRef]

88. Brown, R.R.; Farrelly, M.A. Delivering sustainable urban water management: A review of the hurdles we face. Water Sci. Technol. 2009, 59, 839-846. [CrossRef]

89. Loorbach, D. Transition Management: New Mode of Governance for Sustainable Development; International Books: Utrecht, The Netherlands, 2007.

90. Zegwaard, A.; Zwarteveen, M.; Van Halsema, G.; Petersen, A. Sameness and difference in delta planning. Environ. Sci. Policy 2019, 94, 237-244. [CrossRef]

91. Wardekker, A. Framing 'Resilient Cities': System versus Community Focused Interpretations of Urban Climate Resilience. In Urban Resilience: Methodologies, Tools and Evaluation; Springer: Cham, Switzerland, 2019. (in press)

92. Van Herk, S.; Zevenbergen, C.; Ashley, R.; Rijke, J. Learning and Action Alliances for the integration of flood risk management into urban planning: A new framework from empirical evidence from The Netherlands. Environ. Sci. Policy 2011, 14, 543-554. [CrossRef]

93. Sengers, F.; Wieczorek, A.J.; Raven, R. Experimenting for sustainability transitions: A systematic literature review. Technol. Forecast. Soc. Chang. 2016. [CrossRef]

94. Dolowitz, D.P.; Marsh, D. Learning from abroad: The role of policy transfer in contemporary policy-making. Governance 2000, 13, 5-23. [CrossRef]

95. Runhaar, H.; Mees, H.; Wardekker, A.; Van der Sluijs, J.; Driessen, P. Adaptation to climate change-related risks in Dutch urban areas: Stimuli and barriers. Reg. Environ. Chang. 2012, 12, 777-790. [CrossRef]

96. Kimmelman, H. Mexico City, Parched and Sinking, Faces a Water Crisis. New York Times. 2017. Available online: https://www.nytimes.com/interactive/2017/02/17/world/americas/MexicoCity-sinking.html (accessed on 6 April 2019).

97. Kimmelman, H. The Dutch have Solutions to Rising Seas: The world is Watching. New York Times. 2017. Available online: https://www.nytimes.com/interactive/2017/06/15/world/europe/climate-change-rotterdam. html (accessed on 6 April 2019).

98. Moodley, S. Defining city-to-city learning in southern Africa: Exploring practitioner sensitivities in the knowledge transfer process. Habitat Int. 2019, 85, 34-40. [CrossRef]

(C) 2019 by the authors. Licensee MDPI, Basel, Switzerland. This article is an open access article distributed under the terms and conditions of the Creative Commons Attribution (CC BY) license (http://creativecommons.org/licenses/by/4.0/). 